\title{
Pemberian Ekstrak Daun Kiara Payung (Filicium decipiens (Wight dan Arn.) Thwaites) sebagai Bioherbisida terhadap Pertumbuhan Gulma Babadotan (Ageratum conyzoides L.)
}

\author{
(Giving Kiara Payung (Filicium decipiens (Wight dan Arn.) Thwaites) Leaf Extract as a \\ Bioherbicide for Babadotan (Ageratum conyzoides L.) Weed Growth) \\ Dona Rana ${ }^{*}$ Sendy Rondonuwu, Roni Koneri \\ Program Studi Biologi, Jurusan Biologi FMIPA UNSRAT Manado, 95115 \\ *Email korespondensi: ranadona3@gmail.com
}

(Article History: Received 02 Maret 2020; Revised 20 April 2020; Accepted 06 Mei 2020)

\begin{abstract}
ABSTRAK
Gulma babadotan merupakan masalah serius dalam bidang pertanian karena dapat menurunkan nilai kualitas maupun kuantitas dari tanaman budidaya. Kehadiran gulma dapat diatasi menggunakan senyawa alelokimia dari kiara payung (Filicium decipiens). Penelitian ini bertujuan untuk menguji pengaruh pemberian ekstrak daun kiara payung terhadap pertumbuhan tinggi, panjang akar, berat basah dan berat kering dari gulma babadotan (Ageratum conyzoides). Metode yang digunakan yaitu metode rancangan acak lengkap dengan lima perlakuan yaitu kontrol, ekstrak 1\%, ekstrak 3\%, ekstrak $5 \%$ dan herbisida sintetik 2\%. Uji lanjut BNT taraf 95\% menunjukkan bahwa setelah lima minggu perlakuan terdapat perbedaan yang nyata pada parameter tinggi tanaman antara perlakuan kontrol $(33,4 \mathrm{~cm})$, ekstrak 3\% (27,6 cm), ekstrak 5\% (21,4 cm) dan herbisida sintetik 2\% (14,1 cm). Hasil uji lanjut Games-Howell taraf 95\% menunjukkan bahwa panjang akar perlakuan kontrol $(32,0 \mathrm{~cm})$ tidak berbeda nyata dengan perlakuan ekstrak, tetapi berbeda nyata dengan perlakuan herbisida sintetik $2 \%$ $(3,7 \mathrm{~cm})$. Pada parameter berat basah perlakuan kontrol $(33,81 \mathrm{~g})$ tidak berbeda nyata dengan perlakuan ekstrak tetapi berbeda nyata dengan perlakuan herbisida sintetik $2 \%(0,12 \mathrm{~g})$ dan pada parameter berat kering babadotan tidak ada perbedaan yang nyata antara perlakuan kontrol $(6,86 \mathrm{~g})$ dengan perlakuan ekstrak, tetapi berbeda nyata dengan perlakuan herbisida sintetik $2 \%(0,04 \mathrm{~g})$.

Kata kunci: Kiara payung; bioherbisida; gulma babadotan;ekstrak
\end{abstract}

\begin{abstract}
Babadotan weed is a serious problem for agriculture field because this weed can reduce the quality and quantity value from the cultivated plants. Existence of this weed can control with allelochemical compound from kiara payung (Filicium decipiens). This study aims to examine the effect of giving kiara payung leaf extract for growth, root length, wet and dry weight of babadotan (Ageratum conyzoides) weed. The method use is complete random design method with five treatments that is control, $1 \%$ extract, $3 \%$ extract, 5\% exract and 2\% synthetic herbicide. Further test BNT 95\% show after five weeks treatment there were significant differences in plant height parameter between control $(33.4 \mathrm{~cm}), 3 \%$ extract $(27.6 \mathrm{~cm}), 5 \%$ extract $(21.4 \mathrm{~cm})$ and $2 \%$ synthetic herbicide $(3.7 \mathrm{~cm})$. Further test of Games-Howell $95 \%$ in root length show no significant between control $(32.0 \mathrm{~cm})$ and extract treatment, but significant in $2 \%$ synthetic herbicide $(3.7 \mathrm{~cm})$. In wet weight, control treatment $(33.81$ g) no significant with extract but significant in $2 \%$ synthetic herbicide $(0.12 \mathrm{~g})$, and in dry weight parameter no significant between control $(6.86 \mathrm{~g})$ and extract, but significant in $2 \%$ synthetic herbicide $(0.04 \mathrm{~g})$.
\end{abstract}

Keywords: Kiara payung; bioherbicide; babadotan weed; extract

\section{PENDAHULUAN}

Gulma merupakan tumbuhan yang tidak dibudidayakan, tumbuh liar dan termasuk tumbuhan pengganggu bagi tanaman budidaya dalam memperebutkan unsur hara, air dan cahaya matahari.
Kehadiran gulma yang banyak di sekitar tanaman budidaya dapat menekan pertumbuhan dan perkembangan tanaman budidaya sehingga dapat menyebabkan penurunan hasil produksi, sebagai tempat 
inang hama dan penyakit serta dapat menyebabkan keracunan akibat senyawa yang dikeluarkannya. Salah satu gulma yang mendominasi lahan pertanian yaitu babadotan (Ageratum conyzoides).

Babadotan merupakan gulma berdaun lebar yang mudah menyesuaikan diri dengan berbagai kondisi lingkungan dan mengandung senyawa alelokimia seperti alkaloid, saponin, flavonoid, polifenol, sulfur dan tanin yang dapat menekan pertumbuhan tanaman yang ada di sekitarnya (Khan et al. 2012).

Pengendalian yang dilakukan oleh petani menggunakan herbisida sintetik secara terus menerus dapat mengurangi kesuburan tanah serta mencemari lingkungan. Oleh karena itu lebih dianjurkan untuk menggunakan bioherbisida karena lebih ramah lingkungan. Bioherbisida dapat dibuat dengan memanfaatkan senyawa alelokimia dari akar, batang, daun, bunga maupun biji suatu tanaman (Siregar et al. 2017).

Salah satu tanaman yang dapat dimanfaatkan sebagai bioherbisida adalah kiara payung (Filicium decipiens). Kiara payung merupakan tumbuhan tingkat tinggi yang mengandung senyawa alelokimia seperti saponin, flavonoid, alkaloid, terpenoid, fenol serta tanin yang dapat mempengaruhi pertumbuhan maupun perkembangan tanaman (Khairunnisa et al. 2018).

Penelitian yang telah dilakukan sebelumnya membuktikan bahwa pemberian ekstrak 50\% daun kiara payung dapat menghambat pertumbuhan tinggi, panjang akar dan jumlah daun teki (Cyperus rotundus) (Khairunnisa 2018) dan ekstrak daun kiara payung lebih dari $10 \mathrm{mg} / \mathrm{ml}$ dapat menghambat pertumbuhan tunas dan akar dari Echinochloa crus-galli, Vulpinia myuros, Lolium multiflorum, Phleum pretense, Medicago sativa, Lepidium sativum dan Brassica napus (Bari dan Kato-Noguchi 2017). Penelitian ini bertujuan untuk menguji pengaruh pemberian ekstrak daun kiara payung (Filicium decipiens) terhadap pertumbuhan tinggi, panjang akar, berat basah dan berat kering dari gulma babadotan (Ageratum conyzoides).

\section{METODE}

Penelitian ini merupakan penelitian eksperimen menggunakan Rancangan Acak Lengkap (RAL) yang terdiri dari lima perlakuan ekstrak daun kiara payung yaitu P0 (Kontrol), P1 (Ekstrak 1\%), P2 (Ekstrak 3\%), P3 (Ekstrak 5\%) dan P4 (Herbisida sintetik 2\%).

\section{Penyemaian dan Pemindahan Gulma}

Benih gulma babadotan disemai dalam polybag yang berisi tanah dan pupuk kandang (1:1) kemudian dilakukan penyiraman dua kali sehari. Benih babadotan akan mulai berkecambah setelah dua minggu penyemaian (Santosa et al. 2009). Babadotan dibiarkan hingga berumur delapan minggu kemudian dipindahkan ke polybag perlakuan yang berisi tanah yang telah disterilkan dengan cara pengukusan selama 15 menit selanjutnya ditanam sebanyak tiga tanaman per polybag (Khairunnisa 2018).

\section{Pembuatan Ekstrak Daun Kiara Payung}

Daun kiara payung ditimbang sebanyak $1000 \mathrm{~g}$, kemudian dikeringkan dalam oven dengan suhu $45^{\circ} \mathrm{C}$ selama $5 \times 24$ jam. Daun yang telah kering dihaluskan dan diayak sebanyak dua kali untuk mendapatkan serbuk yang lebih halus. Serbuk daun yang halus ditimbang sebanyak $100 \mathrm{~g}$, kemudian dimaserasi dengan pelarut etanol $96 \%$ (1:5) selama 7x24 jam dan dilakukan pengadukan setiap 1x24 jam (Sahid et al. 2018). Ekstrak disaring pada cawan petri dan diuapkan pada ruangan dengan suhu sekitar $30^{\circ} \mathrm{C}$ sampai kering kemudian dikerok, selanjutnya ditimbang sesuai perlakuan yaitu P1 (1\%) $1 \mathrm{~g} / 100 \mathrm{ml}, \mathrm{P} 2$ (3\%) $3 \mathrm{~g} / 100 \mathrm{ml}$ dan P3 (5\%) $5 \mathrm{~g} / 100 \mathrm{ml}$. Untuk perlakuan herbisida sintetik $2 \%$ dilakukan dengan melarutkan herbisida sintetik basmilang sebanyak $2 \mathrm{ml} / 100 \mathrm{ml}$ 
akuades (Sari et al. 2017a). Ekstrak daun kiara payung dimasukkan ke dalam botol dan diberi label.

\section{Aplikasi dan Penyimpanan Ekstrak}

Ekstrak diaplikasikan sebanyak tiga kali seminggu dengan selang waktu dua hari sekali selama 35 hari. Ekstrak disiram sebanyak $30 \mathrm{ml}$ per polybag atau $10 \mathrm{ml}$ per tanaman (Khairunnisa 2018). Setelah dilakukan penyiraman, ekstrak maupun herbisida sintetik $2 \%$ dimasukkan dalam lemari pendingin untuk menghindari terjadinya fermentasi.

\section{Parameter Perlakuan}

Parameter yang akan diukur yaitu tinggi tanaman, panjang akar, berat basah dan berat kering tanaman. Tinggi tanaman diukur pada awal pengamatan sampai akhir pengamatan dengan selang waktu seminggu sekali. Pengukuran panjang akar dan berat tanaman dilakukan pada hari ke35 setelah perlakuan. Setelah dilakukan pengukuran berat basah, gulma dikeringkan dalam oven dengan suhu $70^{\circ} \mathrm{C}$ selama 48 jam kemudian diukur berat keringnya (Khairunnisa 2018).

\section{Analisis Data}

Hasil dari data yang telah didapat dihitung jumlah, rata-rata dan standar error dari tiap parameter kemudian dilakukan uji normalitas, uji homogenitas, uji variasi satu jalur (One Way Anova) dan uji lanjut menggunakan SPSS. Uji normalitas menggunakan uji Kolgomorov-smirnov dan uji homogenitas menggunakan uji Levene-Test. Jika hasil yang didapat normal dan homogen maka dilanjutkan dengan uji Anova dan jika hasil berbeda nyata dilanjutkan dengan uji BNT (Beda Nyata Terkecil) dengan tingkat kepercayaan 95\%. Jika data normal tetapi tidak homogen maka dilakukan uji BrownForsythe kemudian dilakukan uji Anova dan dilanjutkan dengan uji Games-Howell pada taraf 95\% (Wiharja et al. 2016).

\section{HASIL DAN PEMBAHASAN}

\section{Pengaruh Ekstrak terhadap Tinggi Tanaman}

Hasil uji lanjut BNT taraf 95\% menunjukkan bahwa setelah lima minggu perlakuan terlihat bahwa perlakuan kontrol $(33,4 \mathrm{~cm})$ dan ekstrak $1 \%$ berbeda nyata dengan perlakuan ekstrak $3 \%(27,6 \mathrm{~cm})$, ekstrak $5 \% \quad(21,4 \quad \mathrm{~cm})$ dan herbisida sintetik 2\% (14,1 cm) (Gambar 1). Grafik rerata tinggi tanaman menunjukkan bahwa terjadi penurunan penambahan tinggi tanaman pada tanaman yang diaplikasikan ekstrak sedangkan pada perlakuan herbisida sintetik $2 \%$ sudah tidak terjadi penambahan tinggi tanaman sejak minggu pertama setelah perlakuan (Gambar 2).

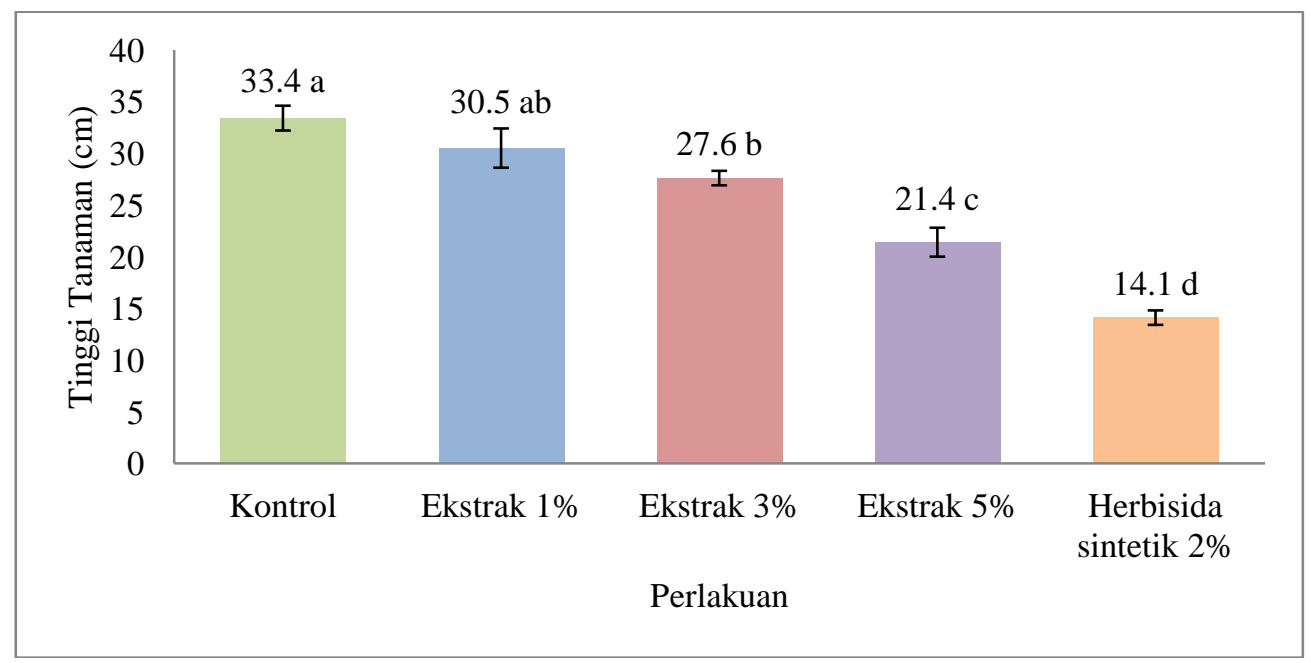

Gambar 1. Tinggi tanaman lima minggu setelah perlakuan (Keterangan: huruf yang berbeda menunjukkan perbedaan yang nyata pada uji BNT taraf 95\%). 


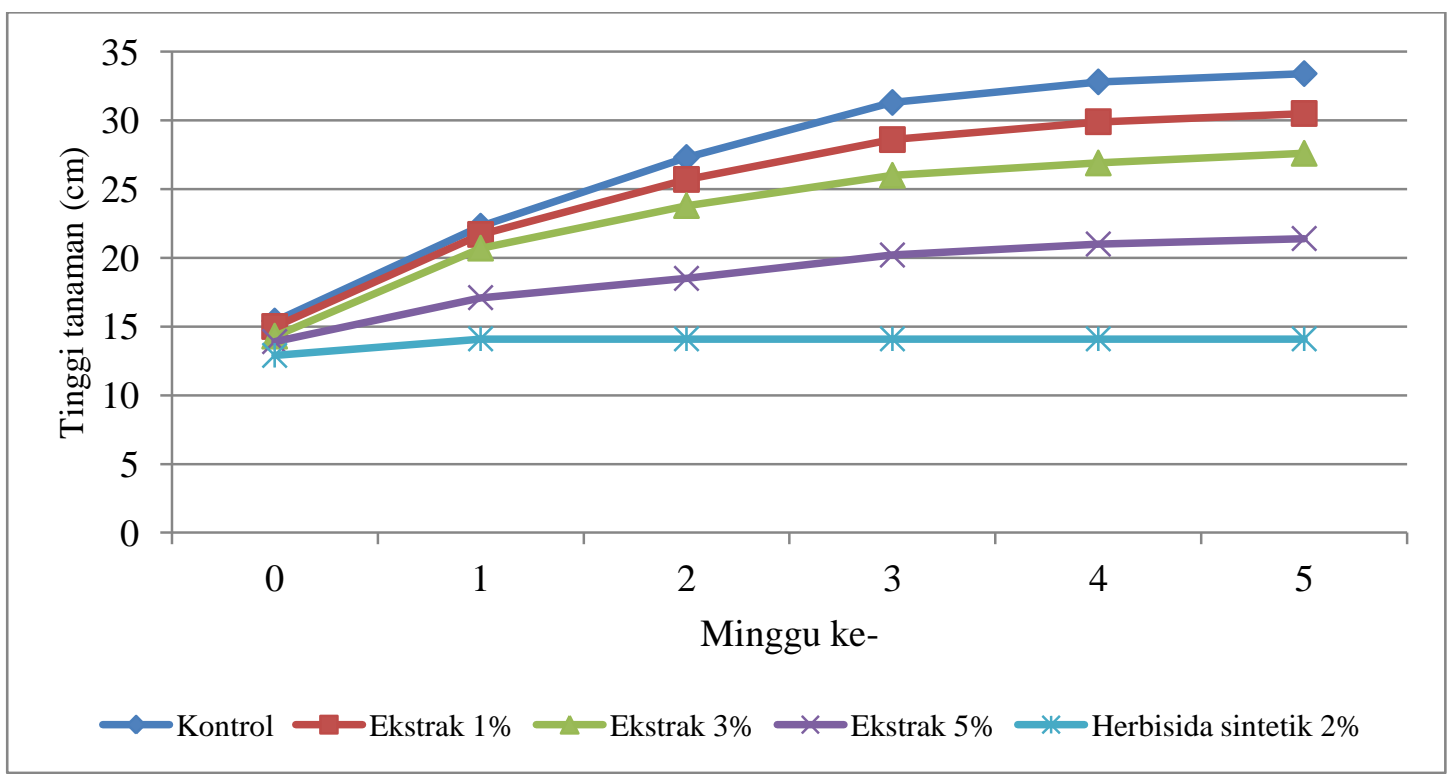

Gambar 2. Grafik rerata tinggi tanaman selama lima minggu perlakuan.

Penurunan penambahan tinggi tanaman diakibatkan oleh senyawa alelokimia yang terserap oleh tanaman sehingga menyebabkan gangguan kerja enzim, hormon tanaman maupun proses fotosintesis pada tanaman serta dapat menyebabkan klorosis maupun nekrosis pada tanaman. Menurut Adin et al. (2017), senyawa alelokimia menghambat pembelahan sel pada meristem apeks pucuk dengan cara menghambat kerja hormon auksin, sitokinin maupun giberelin pada tanaman. Anwar et al. (2013) melaporkan bahwa alelokimia menyebabkan gangguan sintesis protein, kekacauan maupun adanya modifikasi pada struktur membran sel serta dapat menghilangkan fungsi enzim ATP-ase sehingga air maupun ion yang akan masuk menjadi terhambat. Selain itu senyawa berupa fenol, terpenoid maupun flavonoid merusak benang-benang spindel untuk pembelahan sel. Tanaman yang diberikan senyawa alelokimia secara terus menerus dapat menyebabkan keracunan yang berujung pada kelayuan bahkan kematian tanaman. Pada perlakuan herbisida sintetik 2\% menyebabkan kematian gulma sejak minggu pertama perlakuan. Moenandir (2010) dalam Rahmadi (2018) menyatakan bahwa pemberian herbisida glifosat menimbulkan gejala toksik bagi tanaman sejak satu sampai tiga minggu setelah perlakuan yang diakibatkan karena tanaman mengalami keracunan bahan kimia berupa isopropilamina glifosat. Menurut Rahmadi (2018), senyawa glifosat merupakan senyawa dari golongan phosphono amino acid yang dapat menghentikan bahkan mematikan semua organ tanaman yang terkontaminasi.

\section{Pengaruh Ekstrak terhadap Panjang Akar}

Hasil uji lanjut Games-Howell pada taraf $95 \%$ menunjukkan bahwa tidak ada perbedaan yang nyata pada panjang akar tanaman antara perlakuan kontrol $(32,0$ $\mathrm{cm})$, ekstrak $1 \%(30,0 \mathrm{~cm})$, ekstrak $3 \%$ $(23,5 \mathrm{~cm})$ dan ekstrak $5 \%(21,5 \mathrm{~cm})$ tetapi berbeda nyata dengan perlakuan herbisida $\begin{array}{llll}\text { sintetik } 2 \% & (3,7 & \mathrm{cm}) & (\text { Gambar }\end{array}$ 


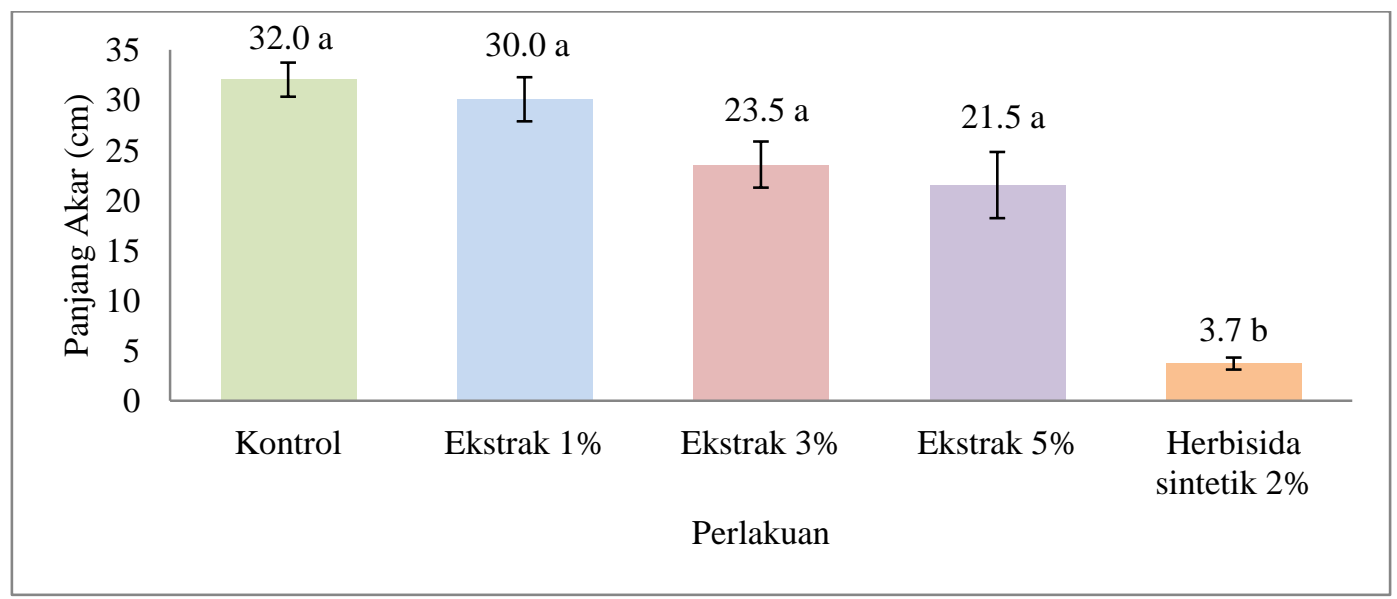

Gambar 3. Panjang akar tanaman setelah lima minggu perlakuan (Keterangan: huruf yang berbeda menunjukkan perbedaan yang nyata pada uji Games-Howell taraf 95\%).

Walaupun secara uji lanjut GamesHowell belum memberikan pengaruh yang nyata tetapi adanya kecenderungan penurunan pada penambahan panjang akar babadotan yang diberi perlakuan ekstrak dengan berbagai konsentrasi. Hal ini disebabkan karena senyawa terpenoid, flavonoid maupun fenol yang terserap oleh akar tanaman menyebabkan terjadinya hambatan dalam pembentukan akar baru karena sel meristem apeks akar sulit untuk membelah (Adin et al. 2017). Menurut Yulifrianti et al. (2015) senyawa fenol pada ekstrak yang diaplikasikan menyebabkan terjadinya gangguan pada transport auksin dari pucuk ke akar yang berfungsi untuk pemanjangan akar dan terjadinya gangguan sintesis sitokinin di bagian akar yang berfungsi untuk pembelahan dan diferensiasi sel akar.

\section{Pengaruh Ekstrak terhadap Berat Tanaman}

Hasil uji lanjut Games-Howell pada taraf 95\% menunjukkan bahwa tidak ada perbedaan yang nyata pada berat basah tanaman antara perlakuan kontrol $(33,81$ g), ekstrak 1\% (31,25 g), ekstrak 3\% $(28,37 \mathrm{~g})$ dan ekstrak $5 \%(23,02 \mathrm{~g})$ tetapi berbeda nyata dengan perlakuan herbisida sintetik 2\% (0,12 g) (Gambar 3). Pada pengukuran berat kering tanaman diperoleh hasil bahwa antara perlakuan kontrol $(6,86 \mathrm{~g})$, ekstrak $1 \%(5,98 \mathrm{~g})$ ekstrak 3\% (5,43 g) dan ekstrak 5\% (3,96 g) tidak berbeda nyata tetapi berbeda nyata dengan perlakuan herbisida sintetik $2 \%$ $(0,04 \mathrm{~g})($ Gambar 4).

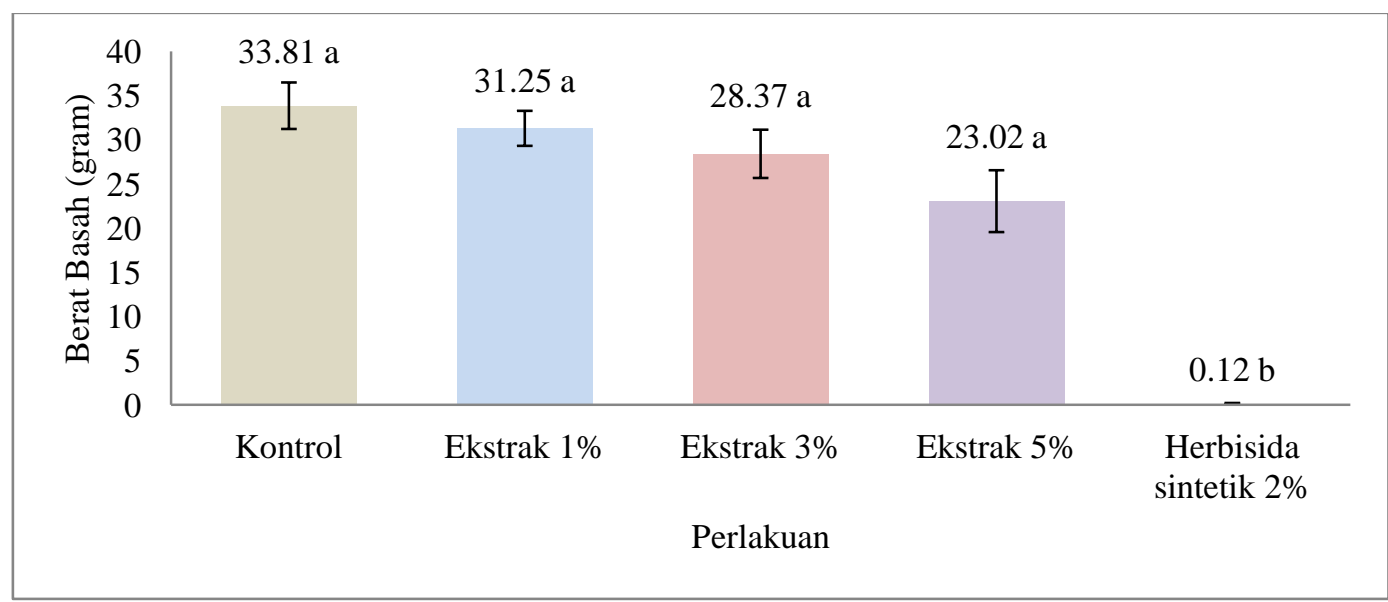

Gambar 4. Berat basah tanaman setelah lima minggu perlakuan (Keterangan: huruf yang berbeda menunjukkan perbedaan yang nyata pada uji Games-Howell taraf 95\%). 


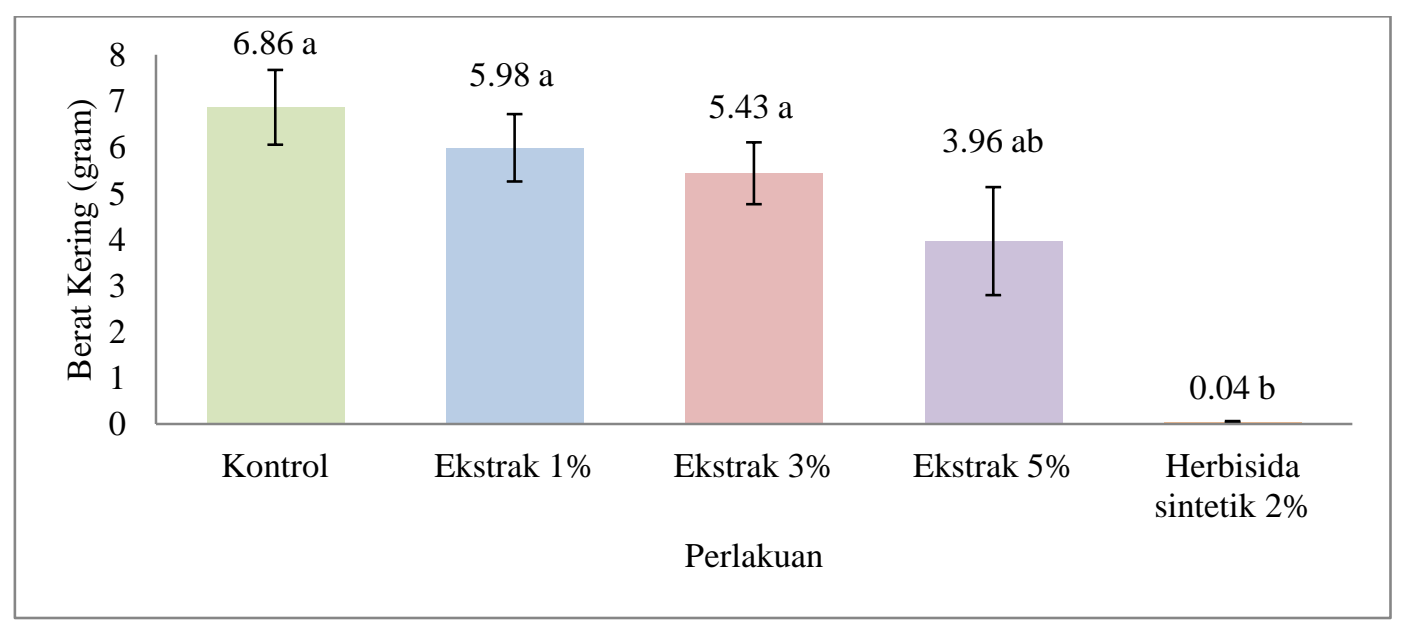

Gambar 5. Berat kering tanaman setelah lima minggu perlakuan (Keterangan: huruf yang berbeda menunjukkan perbedaan yang nyata pada uji Games-Howell taraf 95\%).

Penurunan berat basah dan berat kering tanaman dipengaruhi oleh senyawa alelokimia dari ekstrak kiara payung yang menghambat pemanjangan akar dan pertumbuhan tinggi tanaman. Penurunan kemampuan akar dalam menyerap air serta peristiwa klorosis pada daun menyebabkan terjadinya penurunan kadar air pada tanaman serta terhambatnya proses fotosintesis akibat terjadinya penutupan stomata pada daun yang sangat berpengaruh terhadap berat kering tanaman (Yulifrianti et al. 2015). Senyawa fenol pada ekstrak kiara payung dapat merusak struktur klorofil sehingga terjadi gangguan pada penyerapan cahaya yang mengakibatkan terjadinya penurunan berat kering. Rusaknya struktur klorofil mengakibatkan terjadinya gangguan proses fotosintesis sehingga laju pembentukan makanan menurun. Penurunan laju fotosintesis berakibat terhadap hasil fotosintat sehingga mempengaruhi produksi berat kering tanaman.

\section{KESIMPULAN}

Pemberian ekstrak daun kiara payung dapat menghambat pertumbuhan tinggi tanaman sedangkan pada parameter panjang akar, berat basah maupun berat kering tidak terdapat perbedaan yang nyata tetapi adanya kecenderungan penurunan pada panjang akar maupun berat tanaman baik basah dan kering.

\section{DAFTAR PUSTAKA}

Adin, Wardoyo ERP, Mukarlina (2017) Potensi Ekstrak Gulma Daun Sembung Rambat (Mikania micrantha H.B.K) Sebagai Bioherbisida Pengendali Gulma Putri Malu (Mimosa pudica L.). Jurnal Protobiont 6(1): 1014.

Anwar R, Prihanani, Aswardi R (2013) Uji Berbagai Ekstrak Kulit Jengkol terhadap Pertumbuhan Gulma Echinochloa cruss-galli (L.) Beauv. Jurnal Agroqua 11(2): 13-17.

Bari IN, Kato-Noguchi H (2017) Phytotoxic Effect of Fillicium decipiens Leaf Extract. AmericanEurasian J. Agric. \& Environ. Sci. 17(4): 288-292.

Khairunnisa (2018) Uji Efektivitas Bioherbisida Ekstrak Daun Ketapang, Mahoni dan Kiara Payung terhadap (Cyperus rotundus L.). Skripsi. Fakultas Pertanian Universitas Lampung, Bandar Lampung.

Khairunnisa, Indriyanto, Riniarti M (2018) Potensi Ekstrak Daun Ketapang, Mahoni dan Kiara Payung sebagai Bioherbisida terhadap Cyperus rotundus L. Jurnal EnviroScienteae 14(2): 106-113. 
Khan MS, Tiwari AK, Ji SH, Chun SC (2012) Ageratum conyzoides and its Role in Begomoviral Epidemics; Ageratum enation Virus: An Emerging Threat in India. International Journal of Plant Research 25(2): 20-28

Rahmadi R (2018) Efikasi Herbisida Isopropilamina Glifosat Pada Gulma Perkebunan Karet (Hevea brasiliensis [Muell.] Arg.) Menghasilkan (TM). Skripsi. Fakultas Pertanian Universitas Lampung, Bandar Lampung.

Sahid A, Pandiangan D, Siahaan P, Rumondor MJ (2013) Uji Sitotoksisitas Ekstrak Metanol Daun Sisik Naga (Drymoglossum piloselloides Presl.) terhadap Sel Leukemia P388. Jurnal Mipa Unsrat Online 2(2): 94-99.

Santosa E, Zaman S, Puspitasari ID (2009) Simpanan Biji Gulma dalam Tanah di Perkebunan Teh pada Berbagai Tahun Pangkas. J. Agron. Indonesia. 37(1): 46-54.

Sari VI, Nanda S, Sinuraya R (2017a) Bioherbisida Pra Tumbuh Alang-alang (Imperata cylindrica) Untuk
Pengendalian Gulma di Perkebunan Kelapa Sawit. Jurnal Citra Widya Edukasi 9(3): 301-308.

Siregar EN, Nugroho A, Sulistyono R (2017) Uji Alelopati Ekstrak

Umbi Teki Pada Bayam Duri (Amaranthus spinosus L.) dan Pertumbuhan Tanaman Jagung Manis (Zea mays L. saccharata). Jurnal Produksi Tanaman 5(2): 290 - 298.

Wiharja AR, Surtiningsih T, Salamun (2016) Kajian Variasi Dosis dan Intensitas Pemberian Biofertilizer dalam Meningkatkan Produktivitas Tanaman Terong Hijau (Solanum melongena L. Var. Kenari) Pada Media Tanam Polybag. http://repository.unair.ac.id/53239/. Diakes pada 20 Januari 2020.

Yulifrianti E, Linda R, Lovadi I (2015) Potensi Alelopati Ekstrak Serasah Daun Mangga (Mangifera indica L.) terhadap Pertumbuhan Gulma Rumput Grinting Cynodon dactylon L.). Jurnal Protobiont 4(1): 46-51. 